\title{
sciendo
}

\section{QUALITY OF MOUNTAIN SHEEP MILK USED FOR THE PRODUCTION OF TRADITIONAL CHEESES*}

\author{
Aldona Kawęcka ${ }^{1 \bullet}$, Marta Pasternak ${ }^{1}$, Danuta Słoniewska ${ }^{2}$, Anna Miksza-Cybulska $^{1}$, Emilia Bagnicka $^{2}$ \\ ${ }^{1}$ Department of Sheep Breeding, National Research Institute of Animal Production, \\ 32-083 Balice n. Kraków, Poland \\ ${ }_{2}^{2}$ Institute of Genetics and Animal Breeding, Polish Academy of Sciences, ul. Postępu 36A, \\ Jastrzębiec, 05-552 Magdalenka, Poland \\ •Corresponding author: aldona.kawecka@izoo.krakow.pl
}

\begin{abstract}
The aim of the research was to assess the quality of milk from mountain sheep used for the production of traditional cheeses, taking into account the influence of the breed, the month of milking, and the content of somatic cells. Milk for the study was obtained from sheep of three mountain breeds: Podhale Zackel (PZ), Polish Mountain Sheep (PMS), and Coloured Mountain Sheep (CMS). The sheep were grazed in mountain pastures after lamb weaning, in the period from May to October in the traditional system. No influence of the breed on the examined parameters was found, except for urea content. Mountain sheep milk was characterized by a content of $19.68 \%$ solids, $8.48 \%$ fat, $6.63 \%$ protein, in which almost $76 \%$ was formed by casein $(4.99 \%)$, and the average lactose content was $4.15 \%$. Other milk parameters also did not differ between breeds: density was $1034.04 \mathrm{~g} / \mathrm{L}$, acidity $11.34^{\circ} \mathrm{SH}$, and mean somatic cell content was $982.13 \cdot 10^{3} \cdot \mathrm{ml}^{-1}\left(\log _{10} \mathrm{SCC}=5.68\right)$. The highest urea content was recorded in the milk of Coloured Mountain Sheep $(280.69 \mathrm{mg} / \mathrm{L})$ and the lowest urea content was recorded in the milk of Zackel sheep $(200.97 \mathrm{mg} / \mathrm{L})$. The month of milking influenced the content of most milk components, but no changes in SCC content during lactation were found. Significant correlations between fat content and other milk parameters were recorded. In the case of urea content, negative, statistically significant correlations with the majority of examined parameters were found.
\end{abstract}

Key words: mountain sheep, milk, traditional cheese, quality

Milk-related usage of sheep in Poland is practically limited to a small region of the Polish Carpathians. Mountain sheep are milked by hand on the mountain pasture, and in about 150 days of lactation, sheep provide about 60-70 litres of milk, from

\footnotetext{
*The study was financed from funds of the project: "Directions for use and conservation of livestock genetic resources in sustainable development" co-financed by the National Research and Development Center (Poland) under the Strategic Research and Development Program: "Environment, Agriculture and Forestry" - BIOSTRATEG, decision number BIOSTRATEG2/297267/14/NCBR/2016.
} 
which traditional cheeses are produced (Kawęcka and Krupiński, 2014). The use of mountain sheep and the management of the milk obtained have remained unchanged for centuries.

Raw milk from mountain sheep is used to make excellent, traditional products: żentyca, bundz, bryndza podhalańska, oscypek and redykotka. Bryndza podhalańska was the first Polish product to receive EU protection status as a Protected Designation of Origin (PDO) product. Oscypek and redykołka were registered a while later. Oscypek, classified as a cheese made of steamed mass, is smoked for a few days and acquires a unique taste. Bundz, a fresh rennet cheese, is less durable but very tasty. The ripening of salted and ground bundz produces bryndza, which can be stored for longer. When the whey left over from the production of the cheese is heated the whey proteins curdle and the result is an extremely tasty and nutritious drink zentyca, which can be consumed directly, fresh or after several days of acidification. Redykotka, another EU PDO product, are small cheeses in the shape of animals, hearts or spindles, produced at the end of the grazing season from cheese leftovers. The highlanders give them away to the public during the return of the sheep from the mountain pastures. In recent years other authors have shown results for both products and milk as raw materials for cheese production (Martins et al., 2009; Montel et al., 2014; Kačániová et al., 2018; Pirisi et al., 2011).

Sheep's milk has a higher nutritional value than that of many other mammalian species. It contains more solids, total protein, crude fat, casein and minerals. Sheep's milk also has a higher content of water-soluble vitamins and is more calorific than cow's milk (Balthazar et al., 2007). The chemical composition of milk depends not only on the species of animal, but also on numerous factors such as breed, age, nutrition, month of milking and climatic conditions, which determine the suitability of milk for further processing (Molik et al., 2018). Milk quality is also associated with somatic cell count, which is an indicator of udder health (Li et al., 2014).

Currently, the population of mountain sheep in Poland encompasses three breeds considered to be separate: the Polish Mountain Sheep (PMS), Coloured Mountain Sheep (CMS), and the Podhale Zackel (PZ). All these breeds are perfectly adapted to the difficult local environment, with variable climatic conditions and a short vegetation period. In Poland, so far, there has not been any scientific research available containing a comparison of the quality of these breeds' milk. In addition, SCC limits are clearly described for cattle but insufficiently for sheep, which represents an opportunity to study the problem and, in the future, to work on establishing quantitative limits. Therefore, the aim of this study was to evaluate the quality of milk from three breeds of mountain sheep intended for the production of traditional cheeses, taking into account the influence of the breed, the month of milking, and the content of somatic cells.

\section{Material and methods}

Milk for the study was obtained from sheep of three mountain breeds: Podhale Zackel (PZ), Polish Mountain Sheep (PMS) and Coloured Mountain Sheep (CMS). 
All three breeds were grazed from May to October in one flock on a pasture in the area of the Pieniny range in the Carpathian belt. Traditional, seasonal, collective grazing of mountain sheep takes place in the mountain pastures, after weaning the lambs (rearing with the mothers lasts about 60 days). It is a large-scale grazing area in which the animals spend all day in pastureland and are kept in enclosures at night and during milking. The sheep are hand-milked in the morning and evening. Milk for the study was collected three times during the season: in May (peak of lactation), July (mid-lactation), and September (end of lactation) during evening milking. After milking, representative samples were collected in sterile tubes with preservative and transported to the laboratory. In total, the composition of 135 milk samples, 45 milk samples per breed and per lactation season, was assessed. The composition and parameters of milk were estimated using an IR-spectrophotometer MilkoScan FT2 device (Foss Electric, Hillerod, Denmark). Altogether, 12 parameters were analyzed in each milk sample: fat, protein, casein, total solids, solids-non-fat, lactose percent, free fatty acids (FFA), citric acid, urea content, as well as freezing point (FDP), density and acidity. The somatic cell count (SCC) was determined using fluorescence microscopy (IBCM Bentley Instruments, Inc., Chaska, USA).

The results were compiled statistically using the SAS (SAS/STAT. 20XXX ver. 9.4) package, ver. 9.4 with the analysis of variance method. The basic model was as follows:

$$
y_{i j k l}=B_{i}+M_{j}+S C C_{k}+B * M_{i j}+B * S C C_{i k}+M^{*} S C C_{j k}+e_{i j k l}
$$

where:

$y_{i j k l}-$ investigated traits,

$B_{i}$ - fixed effect of $\mathrm{i}$-th breed $(\mathrm{i}=1-3)$,

$M_{j}$ - fixed effect of the $\mathrm{j}$-th month of milking $(\mathrm{j}=1-3)$,

$S C C_{k}$ - fixed effect of $\mathrm{k}$-th class of somatic cell count $(\mathrm{k}=1-4)$,

$B^{*} M_{i j}$ - fixed effect of $i^{*} \mathrm{j}$-th interaction of breed*month of milking (ij=1-9),

$B * S C C_{i k}$ - fixed effect of ik-th interaction of breed*class of SCC (ik=1-12), $(1-12)$,

$M^{*} S C C_{j k}-$ fixed effect of $\mathrm{jk}$-th interaction of month of milking*class of SCC

$e_{i j k l}-$ random error.

However, because the interactions did not affect fat, total protein, casein, total solids, citric acid, FPD or FFA, the interactions were omitted in the final model for these traits' analysis. The significance of the differences was estimated using the Duncan test. Testing was carried out at the significance levels $\mathrm{P} \leq 0.05$ and $\mathrm{P} \leq 0.01$. In order to determine the effect of somatic cell level on milk quality, the material was divided into four groups according to the number of somatic cells: I - less than $200 \cdot 10^{3} \cdot \mathrm{ml}^{-1}$, II $-200-400 \cdot 10^{3} \mathrm{ml}^{-1}$, III $-401-1000 \cdot 10^{3} \cdot \mathrm{ml}^{-1}$; IV - more than $1000 \cdot 10^{3} \mathrm{ml}^{-1}$. The model for SCC analysis contained the fixed effect of the breed, month of milking, and the interaction between these two effects. Due to the lack of distribution normality, data on the number of somatic cells in milk were logarithmically transformed (decimal logarithm). The correlation coefficient (Spearman corre- 
lation) between individual milk components was also estimated using PROC CORR of the SAS package.

\section{Results}

Table 1 presents the chemical composition and physical characteristics of milk, and the content of somatic cells (SCC and $\log _{10} \mathrm{SCC}$ ) in milk from ewes of three breeds of mountain sheep. No influence of the breed on the examined parameters was found, except for urea content. Mountain sheep milk was characterized by a content of $19.68 \%$ solids, $8.48 \%$ fat, $6.63 \%$ protein, in which almost $76 \%$ was formed by casein $(4.99 \%)$, and the average lactose content was $4.15 \%$. Other milk parameters also did not differ between breeds: density was $1034.04 \mathrm{~g} / \mathrm{L}$, acidity $11.34^{\circ} \mathrm{SH}$, and mean somatic cell content was $982.13 \cdot 10^{3} \cdot \mathrm{ml}^{-1}\left(\log _{10} \mathrm{SCC}=5.68\right)$. The highest urea content was recorded in the milk of Coloured Mountain Sheep (280.69 mg/L) and the lowest was found in the milk of Zackel $(200.97 \mathrm{mg} / \mathrm{L})$.

Table 1. Milk chemical composition, physical traits and SCC depending on breed

\begin{tabular}{|c|c|c|c|c|c|c|}
\hline \multirow{2}{*}{ Item } & \multicolumn{2}{|c|}{ CMS } & \multicolumn{2}{|c|}{ PMS } & \multicolumn{2}{|c|}{$\mathrm{PZ}$} \\
\hline & $\overline{\mathrm{x}}$ & $\mathrm{SD}$ & $\overline{\mathrm{x}}$ & $\mathrm{SD}$ & $\overline{\mathrm{x}}$ & $\mathrm{SD}$ \\
\hline Fat $(\%)$ & 8.58 & 2.52 & 8.58 & 2.21 & 8.30 & 2.39 \\
\hline Protein $(\%)$ & 6.60 & 1.27 & 6.70 & 1.18 & 6.59 & 1.27 \\
\hline Casein $(\%)$ & 4.91 & 1.02 & 5.07 & 0.94 & 4.99 & 0.99 \\
\hline Lactose $(\%)$ & 4.14 & 0.64 & 4.21 & 0.76 & 4.12 & 0.48 \\
\hline TS (\%) & 19.71 & 3.46 & 19.87 & 3.00 & 19.48 & 3.24 \\
\hline SNF (\%) & 11.46 & 1.41 & 11.63 & 1.28 & 11.46 & 1.28 \\
\hline Urea (mg/L) & $280.69 \mathrm{~A}$ & 122.47 & $228.88 \mathrm{~B}$ & 116.37 & $200.97 \mathrm{C}$ & 100.47 \\
\hline Citric acid & 0.10 & 0.04 & 0.12 & 0.04 & 0.11 & 0.05 \\
\hline $\operatorname{FPD}\left(-{ }^{\circ} \mathrm{C}\right)$ & 611.25 & 25.34 & 612.17 & 19.75 & 604.35 & 25.13 \\
\hline FFA (mmol/L) & 0.25 & 0.28 & 0.31 & 0.28 & 0.24 & 0.29 \\
\hline Density (g/L) & 1033.74 & 4.78 & 1034.61 & 4.52 & 1033.77 & 4.02 \\
\hline Acidity (SH) & 11.43 & 2.42 & 11.40 & 2.15 & 11.198 & 2.54 \\
\hline $\operatorname{SCC}\left(10^{3} \cdot \mathrm{ml}^{-1}\right)$ & 901.00 & 1265.21 & 1064.88 & 1467.75 & 976.88 & 1506.09 \\
\hline $\log _{10} \mathrm{SCC}$ & 5.64 & 1.13 & 5.73 & 0.46 & 5.56 & 0.52 \\
\hline
\end{tabular}

$\mathrm{a}, \mathrm{b}, \mathrm{c}-\mathrm{P} \leq 0.05 ; \mathrm{A}, \mathrm{B}, \mathrm{C}-\mathrm{P} \leq 0.01$ - means in rows and denoted using different letters differ statistically significantly. TS - total solids, SNF - solids non-fat, FPD - freeze point depression, FFA - free fatty acids, SCC somatic cell count, $\log _{10} \mathrm{SCC}$ - decimal logarithm of somatic cell count, CMS - Coloured Mountain Sheep, PMS - Polish Mountain Sheep, PZ - Podhale Zackel.

When assessing the influence of the month of milking on milk parameters, statistically significant differences in the content of basic components were found (Table 2). The content of solids, fat, protein and casein increased with the time of lactation, while the content of lactose was lowest in September. The highest increase, by almost $40 \%$, was recorded for fat, which increased to $10.23 \%$ in September com- 
pared to $6.3 \%$ in May. The urea content was higher at the peak of lactation in May than in July and September. The highest values for the freezing point were recorded, as in the case of the primary composition, in September. Similarly, the acidity increased from 9.18 in May to $13.04^{\circ} \mathrm{SH}$ in September. The milking month did not affect the content of citric acid or free fatty acids. There were no statistically significant differences in the somatic cell content.

Table 2. Milk chemical composition, physical traits and SCC depending on the month of milking

\begin{tabular}{l|c|c|c|c|c|c}
\hline \multirow{2}{*}{ Item } & \multicolumn{2}{c}{ May } & \multicolumn{2}{c}{ July } & \multicolumn{2}{c}{ September } \\
\cline { 2 - 7 } & $\overline{\mathrm{x}}$ & $\mathrm{SD}$ & $\overline{\mathrm{x}}$ & $\mathrm{SD}$ & $\overline{\mathrm{x}}$ & $\mathrm{SD}$ \\
\hline Fat (\%) & $6.30 \mathrm{~A}$ & 2.52 & $8.95 \mathrm{~B}$ & 2.21 & $10.23 \mathrm{C}$ & 2.39 \\
Protein (\%) & $5.44 \mathrm{~A}$ & 1.27 & $6.68 \mathrm{~B}$ & 1.18 & $7.77 \mathrm{C}$ & 1.27 \\
Casein (\%) & $4.09 \mathrm{~A}$ & 1.02 & $5.07 \mathrm{~B}$ & 0.94 & $5.81 \mathrm{C}$ & 0.99 \\
Lactose (\%) & $4.25 \mathrm{~A}$ & 0.64 & $4.31 \mathrm{~A}$ & 0.76 & $3.91 \mathrm{~B}$ & 0.48 \\
TS $(\%)$ & $16.67 \mathrm{~A}$ & 3.46 & $20.24 \mathrm{~B}$ & 3.00 & $22.19 \mathrm{C}$ & 3.24 \\
SNF $(\%)$ & $10.46 \mathrm{~A}$ & 1.41 & $11.67 \mathrm{~B}$ & 1.28 & $12.45 \mathrm{C}$ & 1.28 \\
Urea $(\mathrm{mg} / \mathrm{L})$ & $296.16 \mathrm{~A}$ & 122.47 & $192.67 \mathrm{~B}$ & 116.37 & $217.82 \mathrm{~B}$ & 100.47 \\
Citric acid & 0.10 & 0.04 & 0.11 & 0.04 & 0.11 & 0.05 \\
FPD $\left(-{ }^{\circ} \mathrm{C}\right)$ & $590.76 \mathrm{~A}$ & 25.34 & $614.09 \mathrm{~B}$ & 19.75 & $623.07 \mathrm{C}$ & 25.13 \\
FFA $(\mathrm{mmol} / \mathrm{L})$ & 0.27 & 0.28 & 0.28 & 0.28 & 0.26 & 0.29 \\
Density $(\mathrm{g} / \mathrm{L})$ & $1032.1 \mathrm{Aa}$ & 4.78 & $1034.3 \mathrm{~b}$ & 4.52 & $1035.7 \mathrm{~B}$ & 4.02 \\
Acidity (SH) & $9.18 \mathrm{~A}$ & 2.42 & $11.82 \mathrm{~B}$ & 2.15 & $13.04 \mathrm{C}$ & 2.54 \\
SCC $\left(10^{3} \cdot \mathrm{ml} l^{-1}\right)$ & 805.13 & 1234.99 & 1141.07 & 1467.75 & 1006.064 & 1413.83 \\
Log $_{10} \mathrm{SCC}$ & 5.51 & 0.54 & 5.77 & 0.47 & 5.76 & 0.41 \\
\hline
\end{tabular}

$\mathrm{a}, \mathrm{b}, \mathrm{c}-\mathrm{P} \leq 0.05 ; \mathrm{A}, \mathrm{B}, \mathrm{C}-\mathrm{P} \leq 0.01$ - means in rows and denoted using different letters differ statistically significantly. TS - total solids, SNF - solids non-fat, FPD - freeze point depression, FFA - free fatty acids, SCC somatic cell count, $\log _{10} \mathrm{SCC}$ - decimal logarithm of somatic cell count.

The urea content in milk was one of the components that depended on both the breed and the month of milking (Figure 1). Therefore, the influence of the interaction between the breed and the month of milking was also analysed. Statistical analysis showed significant differences for CMS between the content of urea in May and July, and for Podhale Zackel between May and subsequent months. However, there were no differences in urea content in the milk of sheep of the PMS breed between consecutive milkings. The higher urea content in the milk in May compared to subsequent months of milking is probably due to differences in the nutritional value of pasture sward between sampling months. The nutritional value of the sward results from its composition, the age of the plants, and the number of animals. Certainly, the presence of faba beans significantly increases the protein content of the pasture sward taken up by sheep. It should also be borne in mind that sheep eat plants selectively, but also in a variable way, depending on the current demand for nutrients. Therefore, individual plants are not always willingly eaten or are constantly omitted. These animals prefer to eat young, well-leaved plants with low fibre content 
and higher sugar content (Kawęcka et al., 2018). The differences in urea content in milk between breeds may therefore be due to the different taste preferences of sheep of different breeds. Moreover, $\log \mathrm{SCC}$, lactose and SNF content, and density, also depended on breed*month of milking interaction, with the biggest differences in logSCC and lactose content between breeds at the beginning of the trial, e.g. at the peak of lactation (Table 5). The most variable were SNF and density in milk of the CMS breed between months of milking. What is more, the differences between lactose content were stated between SCC classes within CMS and PMS breeds, while no differences for the PZ breed were found. This may mean that despite the high SCC in milk of the PZ breed, caused by internal or external effects, udder homeostasis was maintained. On the other hand, the SCC classes had the biggest influence on lactose and SNF contents, and density in the first month of milking, e,g. in May, maybe because it is around the peak of lactation, when the metabolism of animals' organisms are burdened with the highest milk production. Effects of the interactions for lactose, SNF and density are presented in detail in Tables 5-7.

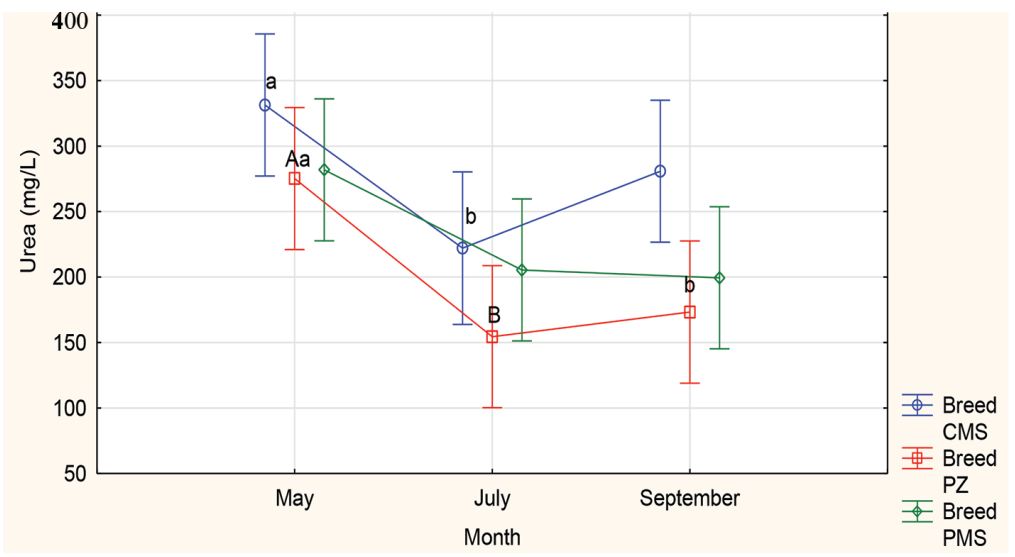

$\mathrm{a}, \mathrm{b}, \mathrm{c}-\mathrm{P} \leq 0.05 ; \mathrm{A}, \mathrm{B}, \mathrm{C}-\mathrm{P} \leq 0.01-$ means for breed and month and denoted using different letters differ statistically significantly.

CMS - Coloured Mountain Sheep, PMS - Polish Mountain Sheep, PZ - Podhale Zackel.

Figure 1. The influence of the breed*month interaction on urea content in milk

Table 3 presents the chemical composition and physical characteristics of milk depending on the somatic cell count. In the studied flock of sheep the highest percentage $(30 \%)$ were ewes in which milk contained somatic cells in the range 200-400 $10^{3} \cdot \mathrm{ml}^{-1}$. The proportion of the remaining three groups of ewes, in which milk was found to contain SCC in the range below 200 and above $400 \cdot 10^{3} \cdot \mathrm{ml}^{-1}$, was similar (about 20\%). It was found that the content of SCC affected most of the studied milk parameters. The lowest content of fat, protein and solids was found in milk with the content below $200 \cdot 10^{3} \cdot \mathrm{ml}^{-1} \mathrm{SCC}$. The highest casein content was observed in milk in the range of SCC content of $200-400$ and $401-1000 \cdot 10^{3} \cdot \mathrm{ml}^{-1}$. The lowest level of lactose (3.63) was recorded for the group of ewes with milk showing more than $1000 \cdot 10^{3} \cdot \mathrm{ml}^{-1}$ SCC. No effect of somatic cell count on urea and citric acid content 
was found. Density and FFA content were lowest for group IV (>1000 SCC), while acidity and freezing point were lowest for group III (400-1000 SCC).

Table 3. Milk chemical composition and physical traits depending on somatic cell counts (SCC)

\begin{tabular}{|c|c|c|c|c|c|c|c|c|}
\hline \multirow{2}{*}{$\begin{array}{c}\mathrm{SCC} \\
\left(10^{3} \cdot \mathrm{ml}^{-1}\right)\end{array}$} & $\begin{array}{c}\mathrm{I} \\
(\mathrm{N}=29)\end{array}$ & $\leq 200$ & II $(\mathrm{N}=42)$ & $200-400$ & III $(\mathrm{N}=34)$ & $\begin{array}{c}401 \\
-1000 \\
\end{array}$ & IV $(\mathrm{N}=30)$ & $>1000$ \\
\hline & $\overline{\mathrm{x}}$ & SD & $\overline{\mathrm{x}}$ & SD & $\overline{\mathrm{x}}$ & SD & $\overline{\mathrm{x}}$ & $\mathrm{SD}$ \\
\hline Fat (\%) & $7.01 \mathrm{~A}$ & 1.69 & $8.82 \mathrm{~B}$ & 2.03 & $9.19 \mathrm{~B}$ & 2.53 & $8.35 \mathrm{~B}$ & 2.61 \\
\hline Protein $(\%)$ & $5.74 \mathrm{~A}$ & 0.74 & $6.90 \mathrm{~B}$ & 1.15 & $7.02 \mathrm{~B}$ & 1.33 & $6.62 \mathrm{~B}$ & 1.23 \\
\hline Casein $(\%)$ & $4.47 \mathrm{~A}$ & 0.56 & $5.30 \mathrm{~B}$ & 0.84 & $5.24 \mathrm{~B}$ & 1.06 & $4.74 \mathrm{~A}$ & 1.13 \\
\hline Lactose (\%) & $4.57 \mathrm{~A}$ & 0.25 & $4.36 \mathrm{~A}$ & 0.32 & $4.03 \mathrm{~B}$ & 0.68 & $3.63 \mathrm{C}$ & 0.79 \\
\hline TS (\%) & $17.82 \mathrm{~A}$ & 1.98 & $20.42 \mathrm{~A}$ & 2.68 & $20.59 \mathrm{~A}$ & 3.56 & $19.32 \mathrm{C}$ & 3.72 \\
\hline SNF (\%) & $11.05 \mathrm{~A}$ & 0.69 & $12.00 \mathrm{~B}$ & 0.93 & $11.77 \mathrm{~A}$ & 1.49 & $10.98 \mathrm{~A}$ & 1.67 \\
\hline Urea (mg/L) & 250.93 & 110.22 & 229.26 & 111.98 & 227.23 & 134.61 & 242.80 & 0.09 \\
\hline Citric acid & 0.11 & 0.03 & $0.12 \mathrm{~A}$ & 0.04 & 0.11 & 0.04 & $0.09 \mathrm{~B}$ & 0.05 \\
\hline $\operatorname{FPD}\left(-{ }^{\circ} \mathrm{C}\right)$ & $598.41 \mathrm{~A}$ & 15.78 & 612.38 & 20.71 & $617.53 \mathrm{~B}$ & 25.25 & 605.16 & 27.56 \\
\hline FFA $(\mathrm{mmol} / \mathrm{L})$ & $0.38 \mathrm{~A}$ & 0.27 & $0.32 \mathrm{~A}$ & 0.30 & $0.23 \mathrm{~B}$ & 0.25 & $0.13 \mathrm{C}$ & 0.26 \\
\hline Density (g/L) & $1034.2 \mathrm{~A}$ & 2.34 & $1035.8 \mathrm{~A}$ & 2.27 & $1034.1 \mathrm{~A}$ & 4.78 & $1031.2 \mathrm{~B}$ & 6.16 \\
\hline Acidity (SH) & $9.97 \mathrm{~A}$ & 1.71 & $11.86 \mathrm{~B}$ & 2.42 & $12.03 \mathrm{C}$ & 2.47 & $11.06 \mathrm{~B}$ & 2.16 \\
\hline
\end{tabular}

$\mathrm{a}, \mathrm{b}, \mathrm{c}-\mathrm{P} \leq 0.05 ; \mathrm{A}, \mathrm{B}, \mathrm{C}-\mathrm{P} \leq 0.01$ - means in rows and denoted using different letters differ statistically significantly. TS - total solids, SNF - solids non-fat, FPD - freeze point depression, FFA - free fatty acids, SCC - somatic cell count.

Table 4. Correlation ${ }^{1}$ coefficients (r) between composition of milk, physical traits and SCC

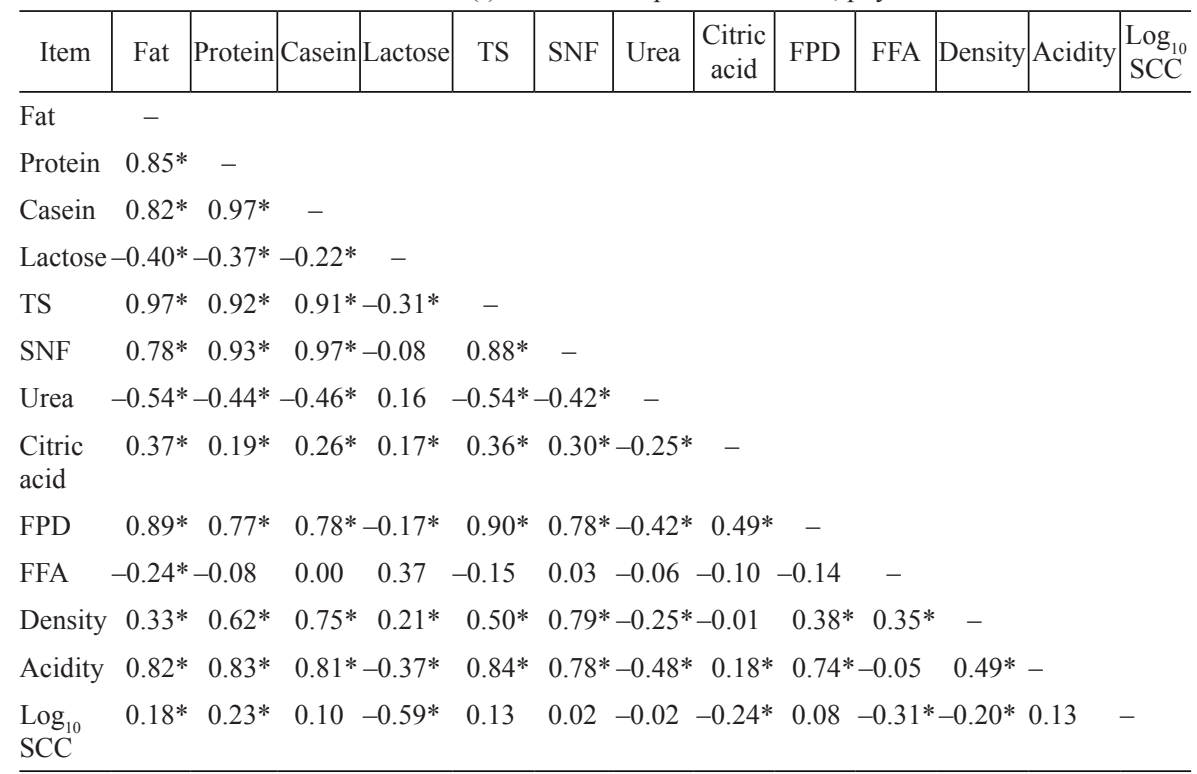

Designated (*) correlation coefficients are significant, with $\mathrm{P}<0.05$.

'Correlation of Spearman's rank order. 
Table 4 presents the correlation coefficients between milk components, physical characteristics and somatic cell content. Statistically significant correlations between fat content and other parameters were recorded. For most of the components and physical properties of milk they were positive, while for lactose, urea and FFA negative correlations were stated, wherein the FFA content was related only to the fat content. As expected, a highly significant negative correlation was found between SCC and lactose content $(-0.59)$. In the case of urea content, negative correlations with the majority of the examined parameters were found.

Table 5. Interaction of breed*month of milking

\begin{tabular}{l|l|l|c|c|c}
\hline \multirow{2}{*}{ Breed } & $\begin{array}{c}\text { Month } \\
\text { of milking }\end{array}$ & SCC & Lactose (\%) & SNF (\%) & Density (g/L) \\
\hline CMS & May & 5.39 & $3.66 \mathrm{~A}$ & $9.60 \mathrm{~A}$ & $1027.88 \mathrm{Aa}$ \\
& July & $5.27 \mathrm{Aa}$ & 3.74 & $10.01 \mathrm{a}$ & 1030.01 \\
& September & $5.87 \mathrm{~b}$ & $4.35 \mathrm{~B}$ & 10.53 & $1034.80 \mathrm{~b}$ \\
\multirow{2}{*}{ PMS } & May & 5.71 & 4.29 & $11.95 \mathrm{~B}$ & $1034.88 \mathrm{~B}$ \\
& July & $5.92 \mathrm{~B}$ & 4.32 & $11.35 \mathrm{~b}$ & 1033.73 \\
& September & 5.67 & 4.50 & 11.85 & 1034.95 \\
PZ & May & 5.84 & 4.14 & $12.33 \mathrm{~B}$ & $1036.11 \mathrm{~B}$ \\
& July & 5.78 & 3.87 & 12.30 & 1035.03 \\
& September & 5.67 & 3.94 & 12.67 & 1036.88 \\
\hline SE & & $0.19-0.21$ & $0.14-0.16$ & $0.24-0.31$ & $0.95-1.19$ \\
\hline
\end{tabular}

$\mathrm{a}, \mathrm{b}, \mathrm{c}-\mathrm{P} \leq 0.05 ; \mathrm{A}, \mathrm{B}, \mathrm{C}-\mathrm{P} \leq 0.01$ - means in columns and denoted using different letters differ statistically significantly; SE - standard error.

Table 6. Interaction of breed*class of SCC

\begin{tabular}{llcccc}
\hline \multicolumn{1}{c|}{ Breed } & \multicolumn{1}{c}{ Class of SCC } & Lactose $(\%)$ & SNF $(\%)$ & Density $(\mathrm{g} / \mathrm{L})$ \\
\hline CMS & $\leq 200$ & $4.44 \mathrm{~A}$ & 11.61 & 1035.61 \\
& $200-400$ & $4.45 \mathrm{Aac}$ & $12.00 \mathrm{a}$ & $1035.59 \mathrm{~A}$ \\
& $401-1000$ & $3.72 \mathrm{bc}$ & 11.07 & 1031.93 \\
& $>1000$ & $3.41 \mathrm{~B}$ & $10.49 \mathrm{~b}$ & $1028.68 \mathrm{~B}$ \\
PMS & $\leq 200$ & $4.61 \mathrm{Aac}$ & 11.75 & 1035.45 \\
& $200-400$ & $4.45 \mathrm{~A}$ & $11.92 \mathrm{a}$ & $1035.76 \mathrm{~A}$ \\
& $401-1000$ & $3.60 \mathrm{bc}$ & 10.65 & 1031.36 \\
& $>1000$ & $3.24 \mathrm{Ba}$ & $10.57 \mathrm{~b}$ & $1029.13 \mathrm{~B}$ \\
$\mathrm{PZ}$ & $\leq 200$ & 4.37 & 11.67 & 1034.99 \\
& $200-400$ & 4.40 & 11.90 & 1036.24 \\
& $401-1000$ & 4.29 & 11.67 & 1033.86 \\
& $>1000$ & $3.99 \mathrm{c}$ & 11.51 & 1034.41 \\
\hline SE & & $0.12-0.20$ & $0.24-0.41$ & $0.93-1.35$ \\
\hline
\end{tabular}

$\mathrm{a}, \mathrm{b}, \mathrm{c}-\mathrm{P} \leq 0.05 ; \mathrm{A}, \mathrm{B}, \mathrm{C}-\mathrm{P} \leq 0.01$ - means in columns and denoted using different letters differ statistically significantly; $\mathrm{SE}$ - standard error. 
Table 7. Interaction of month of milking*class of SCC

\begin{tabular}{l|l|c|c|c}
\hline Month of milking & \multicolumn{1}{c}{ Class of SCC } & Lactose (\%) & SNF $(\%)$ & Density $(\mathrm{g} / \mathrm{L})$ \\
\hline \multirow{4}{*}{ May } & $\leq 200$ & $4.64 \mathrm{~A}$ & $10.79 \mathrm{~A}$ & $1034.03 \mathrm{Aa}$ \\
& $200-400$ & $4.67 \mathrm{Aa}$ & $11.15 \mathrm{Aa}$ & $1034.68 \mathrm{Aa}$ \\
& $401-1000$ & $3.23 \mathrm{~B}$ & $9.32 \mathrm{~B}$ & $1027.08 \mathrm{~b}$ \\
\multirow{3}{*}{ July } & $>1000$ & $3.04 \mathrm{~B}$ & $8.92 \mathrm{~B}$ & $1025.13 \mathrm{~B}$ \\
& $\leq 200$ & 4.42 & 11.74 & 1034.65 \\
& $200-400$ & 4.49 & 11.84 & 1035.21 \\
& $401-1000$ & $4.56 \mathrm{C}$ & $11.78 \mathrm{C}$ & $1035.45 \mathrm{a}$ \\
\multirow{3}{*}{ September } & $>1000$ & $4.03 \mathrm{C}$ & $11.52 \mathrm{C}$ & $1032.77 \mathrm{~A}$ \\
& $\leq 200$ & 4.37 & 12.49 & 1037.36 \\
& $200-400$ & $4.13 \mathrm{~b}$ & $12.83 \mathrm{~b}$ & 1037.70 \\
& $401-1000$ & $3.82 \mathrm{D}$ & $12.29 \mathrm{C}$ & $1034.64 \mathrm{a}$ \\
\hline SE & $>1000$ & 3.58 & $12.12 \mathrm{C}$ & $1034.21 \mathrm{~A}$ \\
\hline
\end{tabular}

$\mathrm{a}, \mathrm{b}, \mathrm{c}-\mathrm{P} \leq 0.05 ; \mathrm{A}, \mathrm{B}, \mathrm{C}-\mathrm{P} \leq 0.01$ - means in columns and denoted using different letters differ statistically significantly; $\mathrm{SE}$ - standard error.

\section{Discussion}

The variability in the composition of sheep's milk is highlighted in many publications. Sheep's milk may contain from $15.42 \%$ to $20.9 \%$ solids, from $4.6 \%$ to $9.05 \%$ fat, and from $4.75 \%$ to $7.2 \%$ protein (Bonczar et al., 2009). The influence of the breed on milk composition was found in earlier studies conducted on Polish mountain sheep breeds and on Weisse Alpenschaf and Bergschaf breeds mountain ewes kept in the same conditions (Kawęcka and Paraponiak, 2006). However, no significant differences in the basic composition of the milk of three mountain breeds were observed in our own study. Ptasińska (2009) found differences in the content of most milk components depending on the breed of sheep and their age. However, similarly as in her own studies, she did not observe any significant differences between the breeds in the content of somatic cells or the freezing temperature of milk. Skoufos et al. (2018), when analyzing the quality of milk of three indigenous Greek breeds (Boutsko, Frisarta, Karagouniko), found differences between breeds only in fat content. The influence of the breed on the composition of sheep's milk in terms of its health-promoting properties was found by Viturro et al. (2015). Differences in milk composition translate into product quality. According to Walisiewicz-Niedbalska (2004) bryndza cheese made from the milk of Polish mountain sheep compared to cheese from the milk of Friesian sheep had more profitable content (more protein, fat, solids, and functional constituents like fatty acids and conjugated linoleic acid isomer cis-9, trans-11). Oscypek cheese, produced with traditional technology from the milk of mountain ewes, contained more calcium and received higher scores in organoleptic evaluation than cow's cheese (Wszołek and Bonczar, 2002). In our own study urea was a component of milk the content of which differed between breeds. Its highest value was found in the milk of Coloured Mountain Sheep (CMS). Urea 
concentration in sheep's milk, similarly to cow's milk, is an indicator of energy and protein balance in diet (Bendelja et al., 2009). Despite significant differences between the breeds, the content of this parameter was within the optimal range. The level of urea in milk indicates the correctness of the protein-energy balance in the rumen, and the content of urea $150-300 \mathrm{mg} / \mathrm{L}$ indicates optimal protein-energy cow nutrition (Salamończyk and Guliński, 2015). Higher urea concentrations in milk of the local Croatian Krk breed compared to the high yielding East Friesian sheep were found by Bendelja et al. (2009). Krk sheep, similar to mountain sheep, spent practically the entire day on pasture, and therefore it can be assumed that the intake of protein was high, which resulted in higher concentrations of urea in milk, but within normal limits. Grazing sheep in mountain pastures completely meets the nutritional requirements of animals, as evidenced, e.g. by the correct level of urea in milk. As mentioned earlier, sheep eat sward plants selectively; they are willing to eat species such as meadow fescue (Festuca pratensis L.), black bent (Agrostis gigantea, Roth), timothy-grass (Phleum pratense L.), perennial ryegrass (Lolium perenne L.), or orchard grass (Dactylis glomerata L.). Sheep are also eager to eat white clover (Trifolium repens L.), ribwort plantain (Plantago lanceolata L.), caraway (Carum carvi L.), common dandelion (Taraxacum officinale F.H. Wiggers coll.) and yarrow (Achillea millefolium) (Skryjka, 1978). In studies parallel to the presented ones, it was shown that in the pastures where the sheep from our study were grazing, many of these plants were present in the pasture sward, e.g. common bent (Agrostis capillaris L.), perennial ryegrass (Lolium perenne L.), white clover (Trifolium repens), and ribwort plantain (Plantago lanceolata L.) (Kawęcka et al., 2018).

The breed had no influence on the other parameters of milk, including acidity, which is a very important parameter of milk evaluation, determining its suitability for processing. Potential acidity of milk, also known as titration acidity, is usually $6.5-7.5^{\circ} \mathrm{SH}$ for cow's milk; acidity of over-acidified milk is about $12^{\circ} \mathrm{SH}$, while acidity lower than $6^{\circ} \mathrm{SH}$ indicates inflammation of the udder or the use of neutralizing additives (Górska and Mróz, 2004). In the case of sheep's milk, the range of variation in titratable acidity is much wider and ranges from 9 to $12^{\circ} \mathrm{SH}$. Bonczar et al. (2009) found a high value of titratable acidity of the fresh milk of mountain sheep $\left(12.70^{\circ} \mathrm{SH}\right)$, whereas in the authors' own research the acidity of mountain sheep milk in three breeds was similar. Ptasińska (2009) found differences in acidity depending on the breed of sheep and grazing area. According to the author, the breed also influenced the freezing temperature of milk, which was not confirmed in the authors' own research. This parameter indicates the physiological condition of the animal's body, including the udder. The values closer to zero indicate abnormal homeostasis, but excessively high values may indicate inflammation of the udder, because in this case the secretion of milk salts is increased (Górecka-Bruzda et al., 2019). The density of milk is the specific mass, defined as the resultant of the density of all the ingredients in the milk. As expected, this parameter had the highest value at the end of lactation, when the content of milk components was highest due to the limitation of the amount of milk produced. The content of free fatty acids indicates the course of the lipolysis process. An increase in FFA in raw milk may adversely affect the sensory and technological characteristics of raw milk (Stádník et al., 2015). 
In our own studies this parameter was similar in all three breeds and did not change with the course of lactation.

The freezing point of milk, regardless of the analyzed factor, was much lower than the one presented in the literature for cow's milk or goat's milk. Much closer to zero reference values are presented either for raw cow milk $(-0.512$ to -0.580 ; Polish Norm PN-A-86002, 1999) or for different dairy cattle breeds maintained in Poland ( -0.544 to -0.536$)$ (Kędzierska-Matysek et al., 2011). The FPD for goat milk seems to be much lower anyway (taking into consideration negative values), with average values of -0.5527 obtained in Canada (Szijarto and van de Voort, 1983) and -0.5544 obtained for Czech goats (Hanuš et al., 2008), while between -0.596 and -0.617 for Polish dairy goats (Polish White Improved and Polish Fawn Improved breeds) (Górecka-Bruzda, 2019). The values obtained in our study are even lower than for goat milk of exotic breeds, while very close to those obtained for dairy goats of the two most common breeds in Poland. According to Janštová et al. (2007), the value of FPD is associated with SNF content in milk - the lower the SNF, the closer the FPD value is to zero. The FPD depends on many factors, including milk components (mainly lactose and chlorides, but also $\mathrm{Ca}, \mathrm{K}, \mathrm{Mg}$, and phosphates), the number and the month of milking, the breed, the feeding and water intake, the health of the mammary gland, and weather conditions (Janstová et al., 2007). The SNF in sheep milk is much higher than in cow or goat milk and therefore FPD in sheep is probably so low.

In the case of the studied mountain sheep the breed did not affect the number of somatic cells contained in milk. However, according to Giaccone et al. (2005), the breed, among other non-infectious factors such as month of milking, type of udder, milking method, etc., can influence the SCC content. In the case of dairy cattle, the somatic cell count in milk is used as an indicator to monitor udder health and provides a basis for assessing the quality and hygienic status of raw material in many countries (Paschino et al., 2019). In goats, the relationship between bacterial infections and SCC is not as obvious as in dairy cattle, due to the species' differences concerning the number and composition of somatic cells in milk from goats and cows, in both healthy and inflamed udders. Milk from healthy goats can contain up to several million somatic cells per millilitre (Kawęcka et al., 2018). In the case of goats a high content of somatic cells in milk from healthy animals is a physiological phenomenon, with about $50 \%$ of these cells constituting the exfoliated secretory epithelium, $70 \%$ of which are living cells (Bagnicka et al., 2011). According to Olechnowicz et al. (2009), the physiological limit of somatic cells content in sheep's milk, depending on the breed, is within the range of $250-300 \cdot 10^{3} \cdot \mathrm{ml}^{-1}$. Studies by Tomáška et al. (2015) showed that almost half of the studied sheep's milk samples contained more than $1 \cdot 10^{6} \cdot \mathrm{ml}^{-1}$. The most numerous group in the studied mountain sheep flock were ewes with milk containing somatic cells within the range of 200-400 $10^{3} \cdot \mathrm{ml}^{-1}$. In the USA the legal limit for SCC set by the Food and Drug Administration is $750000 \mathrm{ml}^{-1}$ for cow's milk and $1000000 \mathrm{ml}^{-1}$ for goat's and sheep's milk (Paape et al., 2007). In the European Union (EU) the legal limit for SCC for cows is $400000 \mathrm{ml}^{-1}$ and there are no legal restrictions for goats and sheep (Regulation (EC) No 853/2004). The results of studies by Leitner et al. (2016) for breeds kept in Israel indicate $2500 \cdot 10^{3} \cdot \mathrm{ml}^{-1}$ as the maximum SCC level for sheep and $3500 \cdot 10^{3} \cdot \mathrm{ml}^{-1}$ for 
goats, above which there is a decrease in the quality of milk, which consequently affects the quantity and quality of the product. Both the results of Ptasińska (2009) and our own studies did not show any significant differences between the breeds in terms of somatic cell content. On the other hand, according to Gonzalo et al. (2005), the breed had a significant effect on the SCC level. Local Spanish Castellana sheep with relatively low milk yields produced milk with SCC content of $692 \cdot 10^{3} \cdot \mathrm{ml}^{-1}$ and Spanish Assaf and Awassi produced twice as much, which the authors said is explained by the higher incidence of systemic infections in higher-yielding breeds. This study also shows the effect of the milking method on the SCC content. Worse hygienic conditions during manual milking compared to machine milking make it difficult for producers to obtain high quality milk. Moreover, the content of SCC did not affect the urea level. In studies by Giaccone et al. (2005) the urea content was lower for milk with high SCC, similarly to the lactose content. In our own studies the lactose level decreased with increasing number of SCC, which was in accordance with the results of Olechnowicz et al. (2009), as well as Vršková et al. (2015). According to Caballero Villalobos et al. (2015), high SCC content was associated with a reduction in lactose content in Manchega sheep's milk and, at the same time, with lower technological parameters of the raw material.

The effect of the month of milking on milk parameters has been confirmed by many authors. Vršková et al. (2015) observed an increase in the protein, fat and lactose content of Tsigai sheep's milk during lactation, while the content of SCC, similar to our own studies, remained practically unchanged throughout the lactation period. Seasonal changes in the composition of milk of the local Sicilian breed of Valle del Belice have been noted by Todaro et al. (2014). Bendelja et al. (2009) demonstrated the effect of the lactation phase on the concentration of urea in milk of the local breed, which was lowest in its initial phase. In our own studies the highest value of this parameter was recorded at the beginning of lactation, in May. The higher urea content obtained in the milk of sheep fed on pastures in May could have resulted from a significant amount of easily degradable protein in the rumen, coming from young pasture sward at the beginning of the season.

As we know, the chemical composition of milk depends on the health status of the udder. Mastitis, the primary indicator of which is an increased number of somatic cells, also causes a decrease in lactose and fat content, and a change in the profile of fatty acids, which is unfavourable for processing. Although there is an increase in total protein content, it results from an increase in whey protein content, which together with the disturbance of the acid-base balance (decrease in $\mathrm{Ca}$ and $\mathrm{P}$ levels) causes a decrease in milk's colloidal stability, sometimes preventing its processing. However, not only does the content of casein proteins decrease, but their proportions change as well (reducing the proportion of $\kappa$ casein on which the formation of curd depends), which also affects the technological parameters of milk. Both active acidity (milk alkalisation) and titratable acidity increase in milk from infected udders (Vivar-Quintana et al., 2006).

Significant correlations between individual milk parameters were confirmed by other authors. Correlations between the content of fat, protein, casein, solids and solids non-fat were estimated at a very high level (0.78 and above), which is not 
consistent with the results of the study on both cow and goat milk, because phenotypic and genetic correlations between the content of fat and protein are estimated at a slightly lower level (about 0.40-0.67) (Bagnicka and Łukaszewicz, 1999; Miglior et al., 2007). A negative correlation between lactose content and protein and fat content was obtained, which is confirmed by the results of phenotypic correlations obtained in studies on cow's milk $(-0.168$ and -0.248 , respectively) (Miglior et al., 2007). However, Bagnicka et al. (2016) obtained opposite results in goat's milk tests (0.62 and 0.54, respectively), but these were genetic correlations. On the other hand, in the foregoing Miglior et al. (2007) study, the genetic correlations between lactose, fat and protein content were basically zero ( 0.013 and 0.080 , respectively). A negative correlation between urea and protein content in milk was also found by Bendelja et al. (2009). Furthermore, Miglior et al. (2007) obtained low positive or almost zero phenotypic correlations between the content of urea and fat and protein in milk ( 0.182 and 0.082 , respectively), but average positive genetic correlations ( 0.425 and 0.200 , respectively). Positive correlation coefficients between SCC and fat and protein content, and negative coefficients for lactose were also found by Olechnowicz et al. (2009). By contrast, in the case of cow's milk, Miglior et al. (2007) estimated almost zero phenotypic correlations between SCC and fat and protein content, while negative correlations were estimated at the mean level for lactose $(0.045,0.093$, -0.227 for fat, protein, and lactose respectively), and negative or zero genetic correlations $(-0.109,0.009$ and -0.202 , respectively). Bagnicka et al. (2016) achieved mean negative or zero genetic correlations for these parameters $(-0.19,0.00$ and -0.14 , respectively). Positive correlation coefficients between SCC and protein content are associated with an increase in the proportion of whey proteins with antibacterial effect, whereas negative correlation between SCC and lactose content is associated with an increase in SCC and a decrease in lactose in the case of inflammatory conditions, and vice versa in the case of healthy udders.

\section{Conclusions}

The milk of the studied mountain sheep breeds did not differ in terms of its basic composition and physical characteristics. The only differentiating parameter was the content of urea, the concentration of which was highest in milk of the Coloured Mountain Sheep variety, but within the normal limits. This may indicate a slightly different nitrogen metabolism in this breed or a selective choice of plants, but given the same animal keeping conditions, further studies are necessary. Month of milking influenced the content of most milk components, but no changes in SCC content during lactation were found. Significant correlations between fat content and other milk parameters were recorded. In the case of urea content, negative statistically significant correlations with the majority of examined parameters were found.

The milk for the production of traditional cheeses from the three studied mountain sheep breeds was characterized by a similar composition of chemical and physical properties and the content of somatic cells. This allows it to be used as a raw material for the production of high-quality traditional cheeses with quality established for years. The only observed differences between the breeds, in the content of urea in milk, indicate the need for further research in this direction. 


\section{References}

B a g n i cka E., Łukaszewicz M. (1999). Genetic and environmental variation of dairy traits in Polish population of goat's. Anim. Sci. Pap. Rep., 17: 59-65.

Bagnicka E., Winnicka A., Jóźwik A., Rzewuska M., Strzałkowska N., K oś c i u c z u k E., Kr z y że w s k i J. (2011). Relationship between somatic cell count and bacterial pathogens in goat's milk. Small Rumin. Res., 100: 72-77.

Bagnicka E., Łukaszewicz M., Ånøy T. (2016). Genetic parameters of somatic cell score and lactose content in goat s milk. J. Anim. Feed Sci., 25: 210-215.

B althazar C., Pimentel T., Ferrão L., A 1 mad a C., Santillo A., Albenzio M., Mollakhalili N., Mortazavian A., Nascimento J., Silva M., Freitas M., Sant' A na A., Gran a to D., Cruz A. (2017). Sheep milk: physicochemical characteristics and relevance for functional food development. Compr. Rev. Food Sci. F., 16: 247-262.

Bendelja D., Antunac N., Mikulec N., Vnučec I., Mašek T., Mikulec Ż., Havran e k J. (2009). Urea concentration in sheep's milk. Mljekarstvo 59: 3-10.

Bonczar G., Reguła-S ardat A., Pustkowiak H., Żebrowska A. (2009). Wpływ substytucji mleka owczego mlekiem krowim na właściwości bundzu. Zywn.-Nauk. Technol. Ja., 66: 96-106.

Caballero Villalobos J., Garzón Sigler A., Oliete B., Arias Sánchez R., Jiménez L., Núñez Sánchez N., Martínez Marín A.L. (2015). Relationship of somatic cell count and composition and coagulation properties of ewe's milk. Mljekarstvo, 65: 138-143.

G i a c c on e P., S c a t a s s a M.L., To d a ro M. (2005). The influence of somatic cell count on sheep milk composition and cheese-making properties. Ital. J. Anim. Sci., 4 (supl. 2): 345-347.

Gonzalo C., Carriedo J.A., Blanco M.A., Beneitez E., Juarez M.T., De La Fuent e L.F., S a n Prim it i v o F. (2005). Factors of variation influencing bulk tank somatic cell count in dairy sheep. J. Dairy Sci., 88: 969-974.

Gór e cka-Bruzda A., Reczyńska D., Jastrzębska E., Barłowska K., B a g ni cka E. (2019). Behavioral and physiological measures in dairy goats with and without SRLV infection. J. Vet. Behav., 31: 67-73.

G ó r s k a A., M r ó z B. (2004). Dependence of natural milk acidity of cows on the farm type and season (in Polish). Med. Weter., 60: 646-647.

H a nu š O., Vy le tělová M., G enču rová V., Hu lová I., L a ndová H. (2008). Differences of some indicators of raw milk properties and especially mineral composition between small ruminants as compared to cows in the Czech Republic. Acta Univ. Agric. Silvic. Mendel. Brun., pp. 51-56.

Janštová B., Dračková M., Navrátilova P., Hadra L., Vorlová L. (2007). Freezing point of raw and heat-treated goat milk. Original Paper Czech J. Anim. Sci., 52: 394-398.

Kačániová M., Terentjeva M., Kunova S., Puchalski C. (2018). Identification of the Slovak traditional cheese "Parenica" microflora. Acta Agraria Debreceniensis, 150: 227-239.

Kaw ę cka A., Krupiński J. (2014). Sheep in the Polish Carpathians: genetic resources conservation of the Podhale Zackel and Coloured Mountain Sheep. Geomatics, Landmanagement and Landscape, 1: 35-45.

K a w ę c k a A., P a r a p o n i a k P. (2006). Evaluation of meat and milk from sheep of different breeds and their crosses, kept under ecological conditions. Ann. Anim. Sci., 6: 283-292.

Kaw ęcka A., Radkowska I., Radkowski A. (2018). Traditional pastoral farming using the example of Jurgowskie Hale near Dursztyn (in Polish). Wiad. Zoot., LVI: 151-158.

K a w ę c k a A., R a d k ow s k a I., S i k o r a J. (2018). Influence of selected factors on the content of somatic cells in the milk of Carpathian goats. Med. Weter., 74: 544-547.

Kędzierska-Matysek M., Litwińczuk Z., Florek M., B arłowska J. (2011). The effects of breed and other factors on the composition and freezing point of cow's milk in Poland. Int. J. Dairy Technol., 64: 336-342.

Leitner G., Lavon Y., Matzrafi Z., Osher B enun O., Bezman D., Merin U. (2016). Somatic cell counts, chemical composition and coagulation properties of goat and sheep bulk tank milk. Int. Dairy J., 58: 9-13. 
Li N., Richoux R., B out inaud M., Mart in P., Gagnaire V. (2014). Role of somatic cells on dairy processes and products: a review. Dairy Sci. Technol., 94: 517-538.

Martins A.P.L., B elo A.T., Vasconcelos M.M., Fontes A.L., P e reira E.A., Belo C. (2009). Characterisation of production system of Niza cheese (PDO): effect of sheep breed on milk composition and coagulation properties. In: Changes in sheep and goat farming systems at the beginning of the 21st century: research, tools, methods and initiatives in favour of a sustainable development, Pacheco F., Morand-Fehr P. (eds). Zaragoza: CIHEAM / DRAP-Norte / FAO, 2009, pp. 221-225.

Miglior F., Sewalem A., Jamrozik J., Bohmanova J., L e febvre D.M., Moore R.K. (2007). Genetic analysis of milk urea nitrogen and lactose and their relationships with other production traits in Canadian Holstein cattle. J. Dairy Sci., 90: 2468-2479.

M o lik E., Bła s i a k M., N a hajło K. (2018). Health benefits of sheep’s milk and factors affecting the content of active compounds in it (in Polish). Prz. Hod., 2: 16-19.

Montel M., Buchin C., Mallet S., Delbes-Paus A., Vuitton C., Desmasures N. (2014). Traditional cheeses: rich and diverse microbiota with associated benefits. Int. J. Food Microbiol., 177: 136-154.

O le c hnow i c z J., J a ś k ow s k i J.M., A n t o s i k P., B u k ow s k a D. (2009). Milk yield and composition in line 05 dairy ewes as related to somatic cell counts. J. Anim. Feed Sci., 18: 420-428.

Pa a e M.J., Wiggans G.R., B annerman D.D., Thomas D.L., S anders A.H., Contrera s A., M or on i P., Miller R.H. (2007). Monitoring goat and sheep milk somatic cell counts. Small Rumin. Res. 68: 1-2, 114-125.

Pas chino P., Vac ca G.M., Dettori M.L., Pazzola M. (2019). An approach for the estimation of somatic cells' effect in Sarda sheep milk based on the analysis of milk traits and coagulation properties. Small Rumin. Res., 171: 77-81.

P ir i s i A., C o m un i a n R., U r g e g h e P.P., S c in t u M.F. (2011). Sheep's and goat's dairy products in Italy: technological, chemical, microbiological, and sensory aspects. Small Rumin. Res., 101: $102-112$.

P t a s iń s k a J. (2009). Assessment of the impact of selected determinants on sheep's milk quality (in Polish). Zesz. Nauk. UE Kraków, 834: 173-187.

Regulation (EC) No 853/2004 of the European Parliament and of the Council of 29 April 2004 laying down specific hygiene rules for food of animal origin. https:/eur-lex.europa.eu/eli/reg/2004/853/2013-0906.

S a la mończyk E., Guliński P. (2015). Differences in the level of urea in milk between standard and extended lactation period and the impact on the environment. Acta Sci. Pol. Zootech., 14: $147-164$.

S koufos I., Giannenas I., Karamoutsios A., Tsinas A., P a padopoulos G., Tzor a A. (2018). Milk quality characteristics of indigenous sheep breeds Boutsko, Frisarta and Karagouniko. J. Hell. Vet. Med. Soc., 68: 59-66.

S tádník L., D u cháč e k J., Toušová R., B e ran J., P táč e k M., Kouřimská L. (2015). Milk components and free fatty acid content. Mljekarstvo, 65: 18-25.

S zijart o L., Van de Vo or t F.R. (1983). Determination of added water and bovine milk to caprine milk. J. Dairy Sci., 66: 620-623.

To d a ro M., B on a n n A., S c a t a s s a M. (2014). The quality of Valle del Belice sheep's milk and cheese produced in the hot summer season in Sicily. Dairy Sci. Technol., 94: 225-239.

To máška M., Hoferi cová M., Kli mešová M., Hanuš O., Vorlová L., Kološta M. (2015). Occurrence of somatic cells in bulk samples of raw sheep's milk (in Czech). In: Proceedings of Food Hygiene and Technology - 45th Lenfeld's and Hökl's Days. Veterinary and Pharmaceutical University of Brno, Brno (Czech Republic), pp. 197-200.

Viturro E., S chlatt 1 M., Ki en berger H., Ry chlik M., P faffl M.W., Frölich K. (2015). Differences in milk fat composition from four old sheep breeds. Arch. Anim. Breed., 58: 351-353.

Vivar-Quintana A.M., Beneitez De La Mano E., Revilla I. (2006). Relationship between somatic cell counts and the properties of yoghurt made from ewes' milk. Int. Dairy J., 16: $262-267$.

Vrš k o vá M., T a n č in V., K i r c h n e r o vá K., S lá m a P. (2015). Evaluation of daily milk production in tsigai ewes by somatic cell count. Potravinarstvo, 9: 206-210. 
Walis iewicz-Niedbalska W., Bodkowski R., Patkowska-Sokola B., Ra madan i S. (2004). Composition of bryndza produced from the milk of Polish Mountain Sheep and Friesian Sheep (in Polish). Zesz. Nauk. Akad. Rol. Wrocław, Zootechnika, 51: 351-356.

W s z ołe k M., B on c z ar G. (2002). The Properties of Oszczypki cheeses made from ewe's, cow's and cow-ewe's milk (in Polish). Przem. Spoż., 56: 14-19.

Received: 17 VI 2019

Accepted: 3 X 2019 